\title{
A Proposal to Ensure Accuracy in Presentence Investigation Reports
}

Over the last century, the American criminal justice system has been shaped by the penal theory that punishment should fit not only the crime but also the rehabilitative needs of the criminal. ${ }^{1}$ Essential to this goal of individualized sentencing and correctional treatment is the availability of a wide range of information about a criminal defendant's background and characteristics. $^{2}$ The Presentence Investigation Report (PSI) is the primary source of such information for all stages of the correctional process. PSIs, however, often contain inaccurate information, which may lead to inappropriate and unfair judgments regarding an offender's sentence, custody conditions, or parole eligibility. ${ }^{3}$ Although Rule 32(c) of the Federal Rules of Criminal Procedure currently permits defendants to challenge the accuracy of information in their PSIs prior to sentencing, ${ }^{4}$ lower

1. See Williams v. New York, 337 U.S. 241, 247 (1949) (noting "prevalent modern philosophy of penology that the punishment should fit the offender and not merely the crime"); M. FRANKEL, CRIMINAL SENTENCING 87 (1972) ("[l]ndividualized rehabilitation is the paramount goal in sentencing."); Bergan, The Sentencing Power in Criminal Cases, ALB. L. REV., Jan. 1949, at 1, 3 (noting modern attempt to fit treatment to the individual rather than punishment to the crime). In keeping with the rehabilitative model, judges have nearly unlimited discretion, within broad statutory limits, to impose appropriate sentences. See M. FRANKEL, supra, at 5-7, 82-85 (describing "wholly unchecked and sweeping powers" of sentencing judges); Cohen, Sentencing, Probation, and the Rehabilitative Ideal: The View from Mempa v. Rhay, 47 TEX. L. REV. 1, 14-15 (1968) (noting common belief that rehabilitative goals "can be best obtained by the preservation of maximum discretion on the part of judicial and correctional authorities").

In recent years the rehabilitative model has come under increasing attack. Critics question the ability of the criminal justice system accurately to classify offenders and predict their future conduct, as premised by the rehabilitative theory. See, e.g., AMERICAN FRIENDS SERVICE COMM., STRUGGLE FOR JUSTICE 40-47 (1971) (theory based on "untenable factual assumptions"); M. FRANKEL, supra, at 88-94 (criticizing "baseless assumption that we are able effectively to understand and uniquely to '(reat' the individual"). As a result, critics argue, the focus on individualized sentencing has led to gross sentencing disparities. See., e.g., 3 STANDARDS FOR CRIMINAL JUSTICE $\S 18-2.2$, at 66 (2d ed. 1980) (rehabilitative model "comes at the cost of tolerating extensive sentencing disparities") [hereinafter cited as STANDARDS].

2. See Williams v. New York, 337 U.S. 241, 247 (1949) ("Highly relevant-if not essential-to [a judge's] selection of an appropriate sentence is the possession of the fullest information possible concerning the defendant's life and characteristics."); Moore v. United States, 571 F.2d 179, 182 (3d Cir. 1978) (such data facilitates tailoring of sentence "to the circumstances of a particular defendant"); Schwellenbach, Information vs. Intuition in the Imposition of Sentence, J. AM. JUDICATURE Soc'Y, Aug. 1943, at 52 (author former United States District Court judge) (such information "only proper basis" for determining appropriate treatment); cf. 18 U.S.C. $\$ 3577$ (1976) ("No limitation shall be placed on the information concerning the background, character, and conduct of a person convicted of an offense which a court of the United States may receive and consider for the purpose of imposing an appropriate sentence.")

3. See infra note 23 (describing uses of PSI by correctional agencies).

4. Rule $32(\mathrm{c})(3)(\mathrm{A})$ provides in pertinent part:

Before imposing sentence the court shall upon request permit the defendant, or his counsel if he is so represented, to read the report of the presentence investigation . . . ; and the court shall afford the defendant or his counsel an opportunity to comment thereon and, at the discre- 
courts have narrowly interpreted this provision to permit challenges to only that information directly relied on by the sentencing judge. ${ }^{5}$ Thus, current Rule 32 procedures tolerate PSI misinformation that may mislead decisionmakers and be detrimental to convicted offenders.

This Note argues that, as interpreted and applied, Rule 32 fails to ensure that only accurate information is used in making sentencing and parole decisions. ${ }^{6}$ The Note contends that the Constitution, Congress' intent in amending Rule 32 and enacting the Parole Commission and Reorganization Act, ${ }^{7}$ and compelling policy considerations all support the right of federal criminal offenders to accuracy of all information relevant to these decisions. It therefore proposes that Rule 32 be amended to permit presentence challenges to any information in the PSI that could affect either sentencing or parole decisions, thereby eliminating the so-called "reliance exception." Finally, the Note examines how the amended rule would affect the sentencing and parole processes and concludes that its likely benefits would outweigh its possible costs.

I. The Presentence Investigation Report and the Criminal Justice Process

Although prepared primarily for use by the sentencing judge, the Presentence Investigation Report is also the principal source of information used to determine the appropriate correctional treatment of the defendant following sentencing. ${ }^{8}$ PSIs, however, are often tainted by misleading or erroneous information about defendants. Cognizant of this problem, Congress amended Rule 32 in 1975 to allow defendants to review their PSIs and challenge inaccuracies prior to sentencing. Yet, due to narrow judicial interpretation and the complex interaction between sentencing and parole, the 1975 amendments have failed to prevent the use of inaccurate PSI information in either sentencing or parole decisions.

\section{A. The Presentence Investigation Report}

The Presentence Investigation Report is prepared by the court's probation office pursuant to Rule 32(c)(1) of the Federal Rules of Criminal

tion of the court, to introduce testimony or other information relating to any alleged factual inaccuracy contained in the presentence report.

FED. R. CRIM. P. 32(c)(3)(A).

5. See infra pp. 1231-33 (discussing PSIs and Rule 32).

6. See infra p. 1233 (sentencing and parole decisions together determine offender's term of incarceration).

7. 18 U.S.C. $\S 4201$ (1976). See infra pp. 1240-41.

8. See R. CARTER, PRESENTENCE REPORT HANDBOOK 3 (1978) (PSI is "critical element in judicial and correctional administration"). 
Procedure. ${ }^{9}$ PSIs vary widely in content, even though they have a standardized format. ${ }^{10}$ Rule 32 requires only that the PSI include a defendant's prior criminal record and any other information that "may be helpful" in his or her sentencing, probation, or correctional treatment." Yet, in keeping with the individualized focus of sentencing, the presentence investigation is generally very broad, ${ }^{12}$ unfettered by formal limitations on the types and sources of information that the report may include.

Typically, the PSI contains a description of the instant offense, consisting of both an "official" version and the defendant's version. ${ }^{13}$ In addition,

9. Use of PSIs in the federal courts developed after the creation of the probation system in 1925 , see Federal Probation Act of 1925, Pub. L. No. 68-596, 43 Stat. 1260 (current version at 18 U.S.C. $\S$ 3655 (1976)), as judges began to rely on local probation officers as sources of information about defendants. See Chandler, The Future of Federal Probation, FED. PROBATION, June 1950, at 41; Kennedy, The Pre-sentence Investigation Report is Indispensable to the Court, FED. PROBATION, Apr.-June 1941, at 3. First enacted in 1946, Rule 32(c)(1) of the Federal Rules of Criminal Procedure codified this practice by requiring probation officers to prepare PSIs unless the court directed otherwise. Pursuant to the current amended Rule 32, a PSI must be prepared for every defendant unless the defendant waives it with the permission of the court, or the court finds that the information in the record is "sufficient to enable the meaningful exercise of sentencing discretion." FED. R. CRIM. P. 32(c)(1). Congress added this provision to Rule 32 in 1975, based on its belief that PSIs "are important aids to sentencing and should not be dispensed with easily." H.R. REP. NO. 247, 94th Cong., 1st Sess. 18, reprinted in 1975 U.S. CODE CONG. \& AD. NEws 674, 690. Currently, PSIs are prepared "in virtually all federal criminal cases." 8A J. MOORE, MOORE'S FEDERAL PRACTICE II 32.03[1], at 33 (rev. 2d ed. 1981); see Note, The Presentence Report: An Empirical Study of Its Use in the Federal Criminal Process, 58 GEO. L.J. 451, 455 (1970) (PSIs prepared for almost 90\% of all federal defendants sentenced).

10. The standard federal procedures manual on writing PSIs directs that PSIs be prepared in accordance with a "Core Concept," which requires that certain essential data appear in the PSI but allows the inclusion of any additional information deemed relevant in a particular case. DIVISION OF Probution, ADMIN. OfFice OF THE U.S. COURTS, The PREsentence InVestightion Report 5-6 (1978) [hereinfter cited as PSI MANUnL]. The "core" categories of information in the PSI are Offense, Prior Record, Personal and Family Data, Evaluation, and Recommendation. Id. at 6. See infra pp. 1227-28 (description of contents of PSIs).

11. FED. R. CRIM. P. 32(c)(2). A defendant's prior criminal record may include not only adult convictions but also arrests, juvenile records, and even "probable unlawful conduct which has not been officially tagged as such." P. KEVE, THE PROBATION OFFICER INVESTIGATES 77 (1960) (handbook for probation officers); PSI MANUAL, supra note 10, at 9-11.

12. The presentence investigation is conducted by the probation officer and typically lasts from three to four weeks. After an initial comprehensive interview of the defendant at the probation office, the probation officer generally seeks additional information about the offense and offender from numerous sources, such as the prosecuting attorney and investigating agents in the case, law enforcement and social service agencies, the military, schools, former employers, financial institutions, and friends, relatives, and associates of the defendant. The probation officer then interviews the defendant again, generally at the defendant's home, in order to elicit additional information and resolve inconsistencies. See Fennell \& Hall, Due Process at Sentencing: An Empirical and Legal Analysis of the Disclosure of Presentence Reports in Federal Courts, 93 HARV. L. REV. 1613, 1623-25 (1980); Gronewold, Presentence Investigation Practices in the Federal Probation System, FED. ProbATION, Sept. 1958, at 27-29. For a detailed treatment of the mechanics of investigating and writing the PSI, see PSI MAN$\mathrm{UAL}$, supra note 10 , at $1-17$; P. KEVE, supra note 11 .

13. The probation officer obtains the defendant's version of the offense from interviews with the defendant. Fennell \& Hall, supra note 12, at 1623-24. The official version is usually obtained from the case file and from discussions with the Assistant United States Attorney. Id. at 1624 n.43; see STANDARDS, supra note $1, \S 18-5.1$, at 345 (prosecutor's case file is a "primary source for the probation officer"). These versions are frequently in disagreement. A recent empirical study of sentencing of white collar defendants found that in $10 \%$ of the 1616 PSIs examined, the defendant's version of the 
the report covers virtually all aspects of a defendant's personal life. ${ }^{14}$ Moreover, probation officers are encouraged to extrapolate from these data and make subjective judgments ${ }^{15}$ about such matters as the offender's attitudes and feelings regarding the crime, and "his or her reactions to opportunities, accomplishments, disappointments, and frustrations." ${ }^{16} \mathrm{Fi}$ nally, the report contains the probation officer's own evaluation of the information in the PSI, a description of sentencing alternatives, and a sentence recommendation. ${ }^{17}$

Judges rely heavily on PSIs to inform their sentencing decisions. ${ }^{18} \mathrm{Be}-$ cause the vast majority of federal criminal defendants who are convicted forego their right to trial by pleading guilty, ${ }^{19}$ the PSI is often the only source of information about the defendant and his or her offense that is available to a sentencing judge. ${ }^{20}$ In addition, judges frequently adopt the probation officer's own synthesis of this information-the sentence recommendation. ${ }^{21}$

offense disagreed with "most or all" of the facts in the official version, while in another $19 \%$ the defendants disagreed with "some" facts. S. Wheeler, Sentencing Study (1979) (unpublished data) (supported by Grant \#78-NI-AX-0017, National Institute of Justice) (on file with Yale Law Journal).

14. The PSI often describes the offender's home life, family, marital history, childhood, religion, mental status, education and employment history, military record, financial status, and physical, psychological, and emotional health. See PSI MANUAL, supra note 10, at 11-15 (prescribing contents of PSIs).

15. Although presentence investigation "requires unusual understanding of the factors of personality, environment, and association that influence human conduct," Chandler, supra note 9, at 42, probation officers need not be trained in psychiatry, psychology, or even social work. The recommended minimum qualifications for probation officers are only a bachelor's degree and two years of experience in "personnel work for the welfare of others." Id. Currently, approximately one-third of all probation officers hold master's degrees. ADMIN. OFFICE OF THE U.S. COURTS, ANNUAL REPORT 228 (1973).

16. PSI MANUAL, supra note 10 , at 4 . The manual warns that "[i]nformation about family, employment, health, and other factors has relatively little value unless interpreted in relation to the defendant's behavior." Id. The purpose of the PSI, therefore, is to "assist in understanding what motivates the defendant's behavior [and] aid in predicting what kinds of behavior may be anticipated in the future." Id.

17. See PSI MANUAL, supra note 10, at 15-16.

18. See United States v. Robin, 545 F.2d 775, 779-80 (2d Cir. 1976) (PSIs "heavily relied upon" by sentencing judges); S. Wheeler, K. Mann \& A. Sarat, The Sentencing of White Collar Offenders, ch. 2, at 11-12 (Oct. 4, 1979) (many judges adapt their decisionmaking styles to the PSI and limit their search for information to this single source) (unpublished manuscript on file with Yale Law Journal) [hereinafter cited as White Collar Offenders].

19. In fiscal $1978,86 \%$ of all criminal defendants who were convicted pleaded guilty or nolo contendre. In fiscal 1979, the figure was $83 \%$. See ADMIN. OFFICE OF THE U.S. COURTS, ANNUAL REPORT OF THE DIRECTOR 286 (1979).

20. See Dickey, The Lawyer and the Accuracy of the Presentence Investigation Report, FED. PROBATION, June 1979, at 28, 29 (PSI main source of information for judge, especially in guilty plea cases); Lehrich, The Use and Disclosure of Presentence Reports in the United States, 47 F.R.D. 225, 227 (1969) (same); see also United States v. Robin, 545 F.2d 775, 780-81 (2d Cir. 1976) (importance of PSI cannot be overemphasized in absence of trial).

21. See W. GAYLIN, PARTIAL JUSTICE 13 (1974) ("In many courts, the probation officer rather than the judge is the sentencer."); Coffee, The Future of Sentencing Reform: Emenging Legal Issues in the Individualization of Justice, 73 MICH. L. REV. 1361, 1369 (1975) (judges generally follow PSI 
After sentencing, the PSI remains the major source of information about the offender during later stages of the correctional process. ${ }^{22}$ The report is influential in determining an inmate's conditions of confinement, participation in programs in prison, level of supervision both while in prison and on probation or parole, and actual length of incarceration. ${ }^{23}$ Although correctional agencies are not bound to accept the PSI at face value, as a practical matter they rarely duplicate the investigation of the probation officer or probe the reliability of the report. ${ }^{24}$ Thus, information in PSIs follows offenders through the correctional system and truly determines their destinies. ${ }^{25}$

Yet PSIs often contain erroneous, incomplete, or misleading information $^{26}$ that can be highly prejudicial to offenders. ${ }^{27}$ Information in PSIs is

sentence recommendations); Fennell \& Hall, supra note 12, at 1617, 1672 (same). Frequent judicial reliance on probation officers' recommendations may be attributable in part to judges' minimal experience in criminal law, see W. GAYLIN, supra, at 13, and in part to their perception of the probation officer as a "professional sentencer" who has had experience with a large number of cases and has indepth familiarity with the defendant at hand, see White Collar Offenders, supra note 18, at 39.

22. See THE PRESIUENT'S COMI'N ON LAW ENFORCEMENT AND ADMIN. OF JUSTICE, TASK FORCE REPORT: CORRECTIONS 19 (1967) (PSI is "major information source in all significant decisions" following sentencing) (hereinafter cited as CORRECTIONS]; Fennell \& Hall, supra note 12, at 1617 \& n.13 (PSI is "basic informational source" in correctional process); cf. United States v. Cesaitis, 506 F. Supp. 518, 520 (E.D. Mich. 1981) (PSI influential in correctional treatment defendant receives). Rule 32(c)(2) recognizes this subsequent function by requiring that the PSI include not only material relevant to sentencing, but also information that "may be helpful . . . in the correctional treatment of the defendant." FED. R. CRIM. P. 32(c)(2).

23. See PSI MANUAL, supra note 10, at 1 (listing uses of PSI). The United States Bureau of Prisons relies on the PSI to determine the type of prison to which an offender should be sent (security level), the degree of supervision he or she should receive while there (custody classification), the treatment, education, and training the offender should receive, and the availability of furloughs and work release. See Rosati v. Haran, 459 F. Supp. 1148, 1152 (E.D.N.Y. 1977); Fennell \& Hall, supra note 12, at 1628. The United States Parole Commission also focuses on the PSI in determining whether and when parole is appropriate for an offender, and the proper conditions of parole. See infra note 56. Although less than half of all those convicted are imprisoned, see ADDIN. OFFICE OF THE U.S. CoURTS, supra note 19, at 287 (44\% of all convicted federal offenders were imprisoned in fiscal 1979, while $41 \%$ were placed on probation), even if the offender is placed on probation, the information in the PSI is used by the probation officer to determine appropriate probation programming and level of supervision. See CORRECTIONS, supra note 22, at 19; Fennell \& Hall, supra note 12, at 1628.

24. See Coffee, supra note 21, at 1369 \& n.25; cf. Project, Parole Release Decisionmaking and the Sentencing Process, 84 Y ALE L.J. 810, 835-36 (1975) (parole authorities rely on offense information in PSI even in face of conflicting accounts from defendants).

25. See Spica, The $A$ to $Z$ of the Presentence Report, FED. Probation, Dec. 1978, at 51 (PSI "present[s] the courts with information that ultimately determines the destiny of offenders"); $c f$. United States v. Fatico, 458 F. Supp. 388, 413 (E.D.N.Y. 1978) (judge predicts result of PSI information linking defendant to organized crime "will probably be five extra years of hard service in a high security prison"), af'd, 603 F.2d 1053 (2d Cir. 1979), cert. denied, 444 U.S. 1073 (1980); Curtis, Federal Judicial Power, Parole Guidelines, and Sentence Reform, in 2 PRISONERS' RIGHTS SOURCEBOOK 91, 99-100 (I. Robbins ed. 1980) (describing impact of Bureau of Prisons and Parole Commission decisions on actual length and harshness of imprisonment).

26. See, e.g., Coffee, supra note 21 , at $1375-76,1395-98$ (PSI may be unreliable and misleading); Lehrich, supra note 20, at 241-45 (mistakes in PSIs are inevitable); Project, supra note 24, at 878 (large number of errors appear in PSIs); White Collar Offenders, supra note 18, at 37-38 (quoting district court judge as stating that PSIs "frequently contain factual errors . . . which often are not caught").

27. See, e.g., United States v. Weston, 448 F.2d 626 (9th Cir. 1971) (vacating sentence changed 
not subject to the protections of the Federal Rules of Evidence, ${ }^{28}$ hence the reports may contain unsubstantiated rumors, hearsay, and other material of questionable relevance or reliability. ${ }^{29}$ The testimony of third persons contained in the PSI may also be colored by hidden biases or misconceptions. ${ }^{30}$ Reliance on undisclosed confidential sources further aggravates the risk of inaccuracy. ${ }^{3 t}$

Official records may be an additional source of misinformation in PSIs. Social agency records are often ambiguous and anecdotal. ${ }^{32}$ Even law enforcement records, the primary source of PSI information, may be inaccurate. Conviction records may be acquired from extra-judicial sources or through telephone inquiries and are rarely verified. ${ }^{33}$ Because of inconsistent reporting policies, police records may list convictions that were subsequently reversed. ${ }^{34}$ Similarly, it may be difficult for the probation officer to ascertain the final disposition of arrests and eliminate possible prejudice from arrests included in the PSI that did not result in conviction. ${ }^{35}$ Fi-

from 5 to 20 years due to uncorroborated PSI allegation that defendant was major drug supplier), cert. denied, 404 U.S. 1061 (1972); State v. Killian, 91 Ariz. 140, 370 P.2d 287 (1962) (vacating 7-10 year sentence based in part on false statement in PSI that defendant had raped juvenile girl); State v. Pohlabel, 61 N.J. Super. 242, 160 A.2d 647 (App. Div. 1960) (vacating seven consecutive three-tofive year sentences, for passing stolen checks totaling approximately $\$ 1500$, that were imposed because PSI falsely characterized defendant as lifelong criminal).

28. See FED. R. EVID. 1101(d)(3) (Rules of Evidence not applicable at sentencing).

29. See United States v. Tucker, 404 U.S. 443, 446 (1972) (dictum) (sentencing judge "largely unlimited either as to the kind of information he may consider, or the source from which it may come"); Gregg v. United States, 394 U.S. 489, 492 (1969) (dictum) ("no formal limitations on contents" of PSIs, which "may rest on hearsay and contain information bearing no relation whatever to the crime with which the defendant is charged"); P. KEVE, supra note 11, at 77-78 ("[r]umor and hearsay may be reported" in PSI); $c f$. United States v. Harris, 558 F.2d 366, 374 (7th Cir. 1977) (hearsay allegations inherently prone to error at sentencing).

30. See STANDARDS, supra note $1, \S 18-6.4$, at 450 (noting "evident possibility that some [sources] will pass along distorted gossip or malicious allegations"); M. FRANKEL, supra note 1, at 29 (PSI may contain "[a]ll kinds of untested assertions and impressions, not always impersonal or lacking in ulterior purposes").

31. See Gardner v. Florida, 430 U.S. 349, 359 (1977) (secrecy conducive to "transmission of confidences which may bear no closer relation to fact than the average rumor or item of gossip").

32. Records from educational institutions, welfare agencies, and psychiatrists and psychologists are regular sources of information in the PSI, see PSI MANUAL, supra note 10, at 13-14, yet they frequently include unverifiable, evaluative information, see STANDARDS, supra note $1, \S 18-5.1$, at 352-54. Although useful in the context for which they were prepared, such records may be highly prejudicial and misleading when used at sentencing. See Coffee, supra note 21, at 1395.

33. See United States v. Janiec, 464 F.2d 126, 127-28 \& n.4 (3d Cir. 1972). In Janiec, the Third Circuit found that "errors are bound to occur" in conviction records, $i d$. at 131 n.11, because "[n]o standards for accuracy are demanded" for obtaining such records, id. at $128 \mathrm{n} .4$, and thus held that presentence disclosure to the defendant of the conviction record in the PSI is constitutionally required.

34. Id. at 129. The court also warned that the PSI "may even list 'convictions' which are unrelated to the defendant and mistakenly attributed to him." Id. See State v. Pohlabel, 61 N.J. Super. 242, 250, 160 A.2d 647, 651 (App. Div. 1960) (finding such a mistake); Project, supra note 24, at 834 n.107 (describing two such incidents).

35. See Project, supra note 24, at 878 n.333 (unknown dispositions major source of inaccuracy in PSI); see also Menard v. Saxbe, 498 F.2d 1017, 1026 (D.C. Cir. 1974) (arrest records rarely amended to show ultimate disposition). The probative value of arrest records, moreover, is open to serious question since they indicate only an encounter with the police. See Schware v. Board of Bar 
nally, law enforcement investigative records are often vague and unsubstantiated, ${ }^{36}$ and are additionally suspect because law enforcement officials do not represent impartial sources of information. ${ }^{37}$

Despite the likelihood of inaccuracies, probation officers typically make only minimal efforts to verify or substantiate the information collected during the presentence investigation. ${ }^{38}$ Furthermore, probation officers themselves often have a marked commitment to "law and order" that may be a source of additional error and bias in PSIs. ${ }^{39}$

\section{B. 1975 Amendments to Rule 32}

To mitigate the problem of inaccurate information in PSIs, Congress amended Rule 32(c) of the Federal Rules of Criminal Procedure in $1975 . .^{40}$ Subdivision (c)(3)(A) now allows a defendant or his or her counsel to review the PSI prior to sentencing and to comment on it at the sentencing hearing. ${ }^{41} \mathrm{~A}$ sentencing judge may withhold from disclosure certain

Examiners, 353 U.S. 232, 241 (1957) (mere fact of arrest "has very little, if any, probative value" as a reflection of misconduct); Coffee, supra note 21, at 1377-82. But see P. KEVE, supra note 11 , at 78 ("information about unproven acts may be highly useful and should be included" in PSIs).

36. These records, concerning criminal behavior with which the defendant has never been charged, tend to focus on general suspicions of unlawful conduct rather than on specific incidents. See Coffee, supra note 21, at 1373, 1384-85; cf. Menard v. Saxbe, 498 F.2d 1017, 1026-27 (D.C. Cir. 1974) (FBI criminal files include virtually any information from local agencies arguably related to criminal activity). The probation officer routinely seeks such information as a source of the defendant's general reputation among law enforcement officials. Yet such data may often consist of little more than bald, conclusory labels such as "major drug supplier," see United States v. Weston, 448 F.2d 626, 628 (9th Cir. 1971), cert. denied, 404 U.S. 1061 (1972), or "[m]ember of a "Black Mafia," see Moore v. United States, 571 F.2d 179, 181 (3d Cir. 1978), with little or no factual foundation or explanation. See United States v. Strother, 578 F.2d 397, 405 n.7 (D.C. Cir. 1978) (although defendant had no record of drug offenses, PSI stated that "the United States Attorney's Office indicated that [defendant] is considered to be a known heroin user and distributor"); STANDARDS, supra note 1 , $\S 18-5.1$, at 345 (law enforcement records "make little effort to distinguish unsupported allegations from those having some indicia of reliability").

37. See Fennell \& Hall, supra note 12, at 1657-58 (law enforcement officials may not be impartial); Note, Procedural Due Process at Judicial Sentencing for Felony, 81 HARV. L. REV. 821,837 (1968) (prosecutor "cannot be expected to be disinterested"). For descriptions of incidents in which law enforcement officials supplied probation officers with one-sided and unreliable information, see Fennell \& Hall, supra note 12, at 1658 n.183; Portman, The Defense Lawyer's New Role in the Sentencing Process, FED. Probhtion, March 1970, at 3, 6.

38. See Coffee, supra note 21 , at 1395 ("no more than a limited effort is made to ensure the reliability of the information collected" for PSIs); Fennell \& Hall, supra note 12, at 1657-58 (probation officers do not independently verify law enforcement information in at least $50 \%$ of their cases).

39. See STANDARDS, supra note $1, \S 18-5.1$, at $344-45$ (some probation officers have prosecutorial bias); $c f$. M. FRANKEL, supra note 1, at 34 (pejorative language of PSIs reflects "fundamental hostility" toward defendants"); Coffec, supra note 21, at 1395-96 (probation officers feel "pressure to extrapolate adverse conclusions about the offender from relatively tenuous informational resources" and have "a preoccupation with adverse information"). But $c f$. Williams v. New York, 337 U.S. 241, 249 (1949) (probation officers "not . . . trained to prosecute but to aid offenders").

40. Federal Rules of Criminal Procedure Amendments Act of 1975, Pub. L. No. 94-64, 89 Stat. 376.

41. See supra note 4 (quoting relevant parts of Rule 32(c)(3)(A)). 
confidential information in the report, ${ }^{42}$ but any undisclosed factual information upon which the judge intends to rely in imposing sentence must be summarized for the defendant. ${ }^{43}$ In addition, if a defendant wishes to contest information contained in the PSI, he or she may, at the discretion of the sentencing judge, introduce evidence relating to any factual inaccuracy in the report. ${ }^{4}$

\section{G. Inadequacies of the 1975 Amendments}

The 1975 amendments have failed to solve the problem of PSI inaccuracy ${ }^{45}$ Although the amended Rule speaks broadly of the defendant's right to challenge "any alleged factual inaccuracy contained in the presentence report," 46 lower federal courts have concluded that hearings to air such challenges are required ${ }^{47}$ only when the disputed information may have been relied on by the judge in imposing sentence. ${ }^{48}$ Under this "reliance

42. FED. R. GRIM. P. 32(c)(3)(A). The judge may withhold "diagnostic opinion which might seriously disrupt a program of rehabilitation, sources of information obtained upon a promise of confidentiality, or any other information which, if disclosed, might result in harm, physical or otherwise, to the defendant or other persons." Id. Also exempted from disclosure is the sentence recommendation of the probation officer. Id.

43. FED. R. CRIM. P. 32(c)(3)(B). The summary may be made orally or in writing and may be made in camera. Any information disclosed to the defendant must also be made available to the prosecuting attorney. FED. R. CRIM. P. 32(c)(3)(C).

44. FED. R. CRIM. P. 32(c)(3)(A). Rule 32 does not specify the procedures applicable at sentencing hearings. See United States v. Robin, 545 F.2d 775, 779 (2d Cir. 1976) (decisions about appropriate procedures left to discretion of sentencing judge); United States v. Fatico, 458 F. Supp. 388, 398 (E.D.N.Y. 1978) (same), aff'd, 603 F.2d 1053 (2d Cir. 1979), cert. denied, 444 U.S. 1073 (1980). The advisory notes to Rule 32 suggest that the sentencing procedure triggered by the comment provision "may be very informal in nature unless the court orders a full hearing." FED. R. CRIM. P. 32 advisory committee note (1974 amendment). Although trial-like hearings are occasionally held, see, e.g., United States v. Ashley, 555 F.2d 462, 466 (5th Cir.) (sentencing hearing held at which three government witnesses testified), cert. denied, 434 U.S. 869 (1977); United States v. Fatico, 458 F. Supp. 388, 391-94 (E.D.N.Y. 1978) (sentencing hearing included testimony from ten government witnesses and cross-examination), such extensive evidentiary hearings are rare. $C$. United States v. Fatico, 603 F.2d 1053, 1057 n.9 (2d Cir. 1979) (sentencing hearing not necessary "every time a defendant disputes facts or statements" in PSI), cert. denied, 444 U.S. 1073 (1980).

45. The Advisory Committee on Criminal Rules of the Judicial Conference recently proposed further amendments to Rule 32 because "rule 32 in its present form is failing to fulfill its purpose ... of promoting accuracy . . . ." Proposed Amendments to FED. R. CRIM. P. 32 advisory committee notes (prelim. draft 1981), reprinted in 30 GRIM. L. REP. (BNA) 3001, 3015 (1981). But cf. infra notes 59-60 (proposed amendments do not address inadequacies of Rule 32).

46. FED. R. CRIM. P. 32(c)(3)(A).

47. On its face, Rule 32 (C)(3)(A) never mandates a hearing, but leaves the decision to the discretion of the judge. Nonetheless, courts have concluded that when a defendant raises a substantial challenge to information relied on at sentencing, a hearing is required. See, e.g., United States v. Robin, 545 F.2d 775, 779 (2d Cir. 1976) (when PSI information is challenged, "a court's failure to take appropriate steps to ensure the fairness and accuracy of the sentencing process must be held to be plain error and an abuse of . . . discretion"); United States v. Espinoza, 481 F.2d 553, 557 (5th Cir. 1973) (hearing required because judge's discretion must "be exercised in a manner consistent with the purposes of informed and appropriate sentencing").

48. In numerous cases, courts have upheld sentences despite alleged PSI inaccuracies because the sentencing judges did not rely on the challenged information. See, e.g., Knight v. United States, 611 F.2d 918, 923 (1st Cir. 1979); United States v. Missio, 597 F.2d 60, 61-62 (5th Cir. 1979) (per 
exception," courts presume that PSI misinformation not taken into account by the sentencing judge had no impact on the sentence imposed and thus constitutes "harmless error."

This interpretation of Rule 32 should ensure accurate sentencing information, although not error-free PSIs. In practice, however, even misinformation not directly considered at sentencing may adversely affect offenders through reliance by the Parole Commission and implicit reliance at sentencing. Because both of these consequences arise from the intimate relation between sentencing and parole in the federal system, that interaction must first be clearly understood.

The decision of the sentencing judge alone does not determine the amount of time an offender actually spends behind bars. Responsibility for this decision is shared by the sentencing judge, who imposes a maximum and, occasionally, a minimum term to be served, ${ }^{50}$ and the United States Parole Commission, which decides when, between those extremes, an offender should be released. ${ }^{51}$ In effect, the sentencing process spans both of these decisions. ${ }^{52}$

curiam); Wixom v. United States, 585 F.2d 920, 921 (8th Cir. 1978) (per curiam). Although these cases do not expressly rely on Rule 32 , they recognize that unless allegedly false information is considered by the sentencing judge, see supra note 47 , the judge may refuse, at his or her discretion, to hear evidence on the claim.

In order to challenge a sentence on appeal, a defendant generally need only establish a possibility that the sentencing judge was influenced by misinformation. See, e.g., United States v. Robin, 545 F.2d 775, 779 (2d Cir. 1976) (hearing required when "possibility of reliance on misinformation is shown"); United States v. Bass, 535 F.2d 110, 118 (D.C. Cir. 1976) (relief granted when "significant possibility that misinformation infected [sentencing] decision"); McGee v. United States, 462 F.2d 243, 247 (2d Cir. 1972) (remanding case because reliance "not improbable"). But cf. Knight v. United States, 611 F.2d 918, 923 (1st Cir. 1979) (implying that actual reliance must be demonstrated); United States v. Stevenson, 573 F.2d 1105, 1107 (9th Cir. 1978) (same). Any explicit indication in the sentencing record that the judge disclaimed reliance on disputed information, therefore, will suffice to insulate a sentence from challenge. But see United States v. Battaglia, 478 F.2d 854, 854 (5th Cir. 1972) (per curiam) (post-sentencing judicial disclaimer of reliance does not obviate need for hearing "at which [defendant] may seek to remove any lingering doubt the court may have had").

49. Cf. Smith v. United States, 565 F.2d 378, 379 (5th Cir. 1978) (per curiam) ("If the sentence would remain the same without regard to the [disputed information], no evidentiary hearing would be necessary.") But cf. infra pp. 1235-37 (such misinformation may have a significant adverse effect on both the offender's sentence and actual length of incarceration). The Advisory Committee of the Judicial Conference has apparently accepted the existence of a reliance exception to Rule 32 . Its tentative draft of proposed amendments to Rule 32 requires that, for every PSI inaccuracy alleged by the defendant, the sentencing judge either make a finding on the dispute or determine "that no such finding is necessary because the matter controverted will not be taken into account in sentencing." Proposed Amendments to FED. R. CRIM. P. 32(c)(3)(D) (prelim. draft 1981), reprinted in 30 CRIM. L. REP. (BNA) 3001, 3014-15 (1981).

50. See 18 U.S.C. \& 4205(b) (1976).

51. 18 U.S.C. $\S 4205$ (a) (1976). All prisoners sentenced to a term of imprisonment of more than one year may be eligible for release on parole. Id. Those sentenced under 18 U.S.C. § 4205(b)(1) become eligible upon completion of their minimum terms as set by the sentencing judge, or at onethird of the maximum sentence imposed if no minimum was set. Those sentenced under 18 U.S.C. $\S$ 4205(b)(2) are eligible for immediate parole.

52. See infra p. 1238 (parole tantamount to deferred stage in sentencing process); $c f$. Curtis, supra note 25 , at $98-100$ (describing sentencing process as beginning with arresting officer and ending with 
Federal parole release decisions are made on the basis of two main factors, severity of the offense ${ }^{53}$ and potential risk of parole violation, ${ }^{54}$ in accordance with established "parole guidelines." 55 In most cases the PSI contains all the information that the Parole Commission uses to assess these variables and make release decisions. ${ }^{56}$ PSI accuracy is, therefore, essential for parole as well as sentencing.

parole authority). Although in the federal system sentencing should be viewed as the combined actions of the judge and Parole Commission, for convenience this Note will continue to refer to the decision of the sentencing judge as "sentencing."

53. Offense severity is divided into seven categories, ranging from "Low" to "Greatest II." See 28 C.F.R. $\$ 2.20$ (1981). The severity of an offense is determined by ranking an inmate's particular offense behavior in relation to a wide range of federal crimes. See Hoffman \& Stover, Reform in the Determination of Prison Terms: Equity, Determinacy, and the Parole Release Function, 7 HOFSTRA L. REV. 89, 103 (1978) (description of "offense severity"); Project, supra note 24, at 823-24 (same). In rating offense severity, the Parole Commission may look behind the legal offense that resulted in conviction to the "actual offense behavior that occurred." U.S. PAROLE COMM'N, RULES AND PROCE. DURES MANUAL 122 (Mar. 1, 1982) [hereinfter cited as PAROLE MANUAL]. Thus, charges that were dismissed pursuant to a plea bargain or unadjudicated allegations that aggravate the severity of the offense will usually be taken into account in establishing offense severity. Id.

54. The risk of parole violation is quantified on the basis of the "Salient Factor Score," a tenpoint index calculated from six factors relating to an inmate's criminal record and drug history. See 28 C.F.R. $\$ 2.20$ (1981). The score "is designed as an actuarial parole prognosis aid," PAROLE MANU $\Lambda$ L, supra note 53, at 128: the higher an inmate's score, the greater the statistical likelihood that he or she will succeed on parole. See Flaxman, The Hidden Dangers of Sentencing Guidelines, 7 HoF. STR L L. REV. 259, 266-67 nn.51-52 (1979) (describing statistical correlation between salient factor score and success on parole).

55. The parole guidelines were promulgated pursuant to the Parole Commission and Reorganization Act, 18 U.S.C. $\S 4201,4203$ (a) (1976), and are codified at 28 C.F.R. $§ 2.20$ (1981). There are separate guidelines for adult and youth offenders. The guidelines "indicate the customary range of time to be served before release for various combinations of offense (severity) and offender (parole prognosis) characteristics." 28 C.F.R. $\$ 2.20$ (b) (1981). These variables make up the vertical and horizontal axes, respectively, of a parole matrix. By categorizing an offender's offense severity and salient factor score in comparison with other offenders, see infra notes 53-54, and plotting this information on the parole matrix, the appropriate range of months to be served prior to parole release is determined. See generally A. PARTRIDGE, A. CHASET, \& W. EldRIDGE, POLICIES OF THE PAROLE COMMISSION AND THE BUREAU OF PRISONS AS THEY AFFECT THE JUDGE'S SENTENCING OPTIONS 820 (rev. ed. 1979) (describing construction and operation of parole guidelines [hereinafter cited as CORRECTIONAL POLICIES]; Curtis, supra note 25, at 103-04 (same).

56. See Curtis, supra note 25, at 106 (PSI is primary document Parole Commission uses); Fennell \& Hall, supra note 12, at 1617 n.13 (same); Project, supra note 24, at 878 (same). Under the parole guidelines, institutional adjustment and rehabilitative progress play only minor roles in parole release decisions. See Moore v. Nelson, 611 F.2d 434, 438 (2d Cir. 1979) (rehabilitation plays a minor part in parole); Curtis, supra note 25, at 103 (rehabilitative progress irrelevant to release decision). Because the Parole Commission can only grant parole to inmates who have "substantially observed the rules of the institution," 28 C.F.R. $\$ 2.18$ (1981), however, inmate misbehavior may adversely affect the parole decision, although satisfactory conduct generally has no effect. See Moore, 611 F.2d at 438 n.8. See also CORRECTIONAL POLICIES, supra note 55, at 8 (offender can do little within institution to change parole date "other than violate the rules").

Although the Parole Commission has authority to set parole dates outside of the guideline range upon a showing of good cause, see 18 U.S.C. $\$$ 4206(c) (1976), even those decisions are likely to be based on mitigating or aggravating information contained in the PSI. Cf. PAROLE MANUAL, supra note 53, at 125-28 (sophistication of offense, vulnerability of victim, and unusually extensive prior record listed as reasons for decisions above guideline ranges). In any case, the vast majority of release decisions fall within the parole guidelines. See United States v. Salerno, 538 F.2d 1005, 1007 (3d Cir. 1976) ("overwhelming majority"); Grasso v. Norton, 376 F. Supp. 116, 119 (D. Conn. 1974) (9294\%), aff', 520 F.2d 27 (2d Cir. 1975). 
Yet Rule 32 fails to prevent the use of PSI misinformation in parole release decisions. When imposing sentence, a judge may choose to disregard material in the PSI that could be central to the parole decision. ${ }^{57}$ Due to the "reliance exception" to Rule 32, such information, even if false, is currently not subject to presentence challenge. ${ }^{58}$ This information, rather, is communicated to the Parole Commission untested ${ }^{59}$ and may lead to an inappropriate parole decision. ${ }^{60}$

Indeed, offenders are even more vulnerable to errors in the PSI at the parole stage than at sentencing. The Parole Commission makes little ef-

57. In many cases, judges disclaim reliance at sentencing on information that would affect the calculation of an offender's parole guidelines. See, e.g., Wixom v. United States, 585 F.2d 920, 921 (8th Cir. 1978) (per curiam) (unsubstantiated criminal activities); Cochran v. United States, 567 F.2d 1288, 1289 (5th Cir. 1978) (per curiam) (invalid prior convictions); United States v. Yates, 554 F.2d 342, 343 (7th Cir.) (additional drug sales), cert. denied, 434 U.S. 865 (1977); United States v. Herndon, 525 F.2d 208, 210 (2d Cir. 1975) (\$35 per week cocaine habit); United States v. Allen, 494 F.2d 1216, 1217 (3d Cir.) (description as "a major non-addict pusher of heroin"), cert. denied, 419 U.S. 852 (1974); Putt v. United States, 363 F.2d 369, 370 (5th Cir.) (per curiam) (rape of minor female and conviction for burglary), cert. denied, 385 U.S. 962 (1966). In the few reported cases in which offenders have sought to remove allegedly inaccurate material from their PSIs on the grounds that it could adversely affect their parole decisions, courts have uniformly held that such challenges must be resolved at the parole stage because the information was not relied on at sentencing. See United States v. Stevenson, 573 F.2d 1105, 1107-08 (9th Cir. 1978); United States v. Cesaitis, 506 F. Supp. 518, 522-23 (E.D. Mich. 1981) (invalid convictions); Rosati v. Haran, 459 F. Supp. 1148, 1150 (E.D.N.Y. 1977) (description as "'mule' for a well organized heroin ring").

58. See supra p. 1232 \& note 48 (discussing reliance exception).

59. Under current sentencing practices, the Parole Commission may even rely on information that was challenged at sentencing. Although PSI information a judge finds to be erroneous or unreliable at a Rule 32 hearing may not be relied on in imposing sentence, see infra pp. 1237-38 (sentence based on inaccurate information violates due process), such information remains in the PSI for subsequent consideration by the Parole Commission and Bureau of Prisons. See Rosati v. Haran, 459 F. Supp. 1148,1154 (E.D.N.Y. 1977) (Rule 32 challenge addresses only whether court can rely on disputed information, not propriety of including the material in the PSI). In fact, the Commission is rarely notified of the existence or outcomes of PSI challenges at sentencing. See Fennell \& Hall, supra note 12 , at 1680 (fewer than one fourth of district courts inform correctional agencies of PSI challenges at sentencing). Although the proposed amendments to Rule 32 would require that a record of all PSI challenges be prepared for correctional agencies, Proposed Amendments to FED. R. CRIM. P. 32(c)(3)(D) (prelim. draft 1981), reprinted in 30 CRIM. L. REP. (BNA) 3001, 3014-15 (1981), even when the Parole Commission is aware of Rule 32 challenges, it is not bound to accept the findings of the court. See infra note 119.

60. Sec, e.g., United States ex rel. Petri v. Warden, Allenwood Fed. Prison Camp, 507 F. Supp. 5, 7 (M.D. Pa. 1980) (plaintiff claims adverse parole decision based on PSI misinformation); Payton v. Thomas, 486 F. Supp. 64, 68 (S.D.N.Y. 1980) (same); cf. Wixom v. United States, 585 F.2d 920, 921 (8th Cir. 1978) (per curiam) ("inappropriate" for Parole Commission to consider any disputed information not relied on by sentencing judge). The Advisory Committee of the Judicial Conference has warned of the danger that "[u]nder current practice," the Parole Commission "will place great reliance upon factual assertions in the [PSI] which are in fact untrue and which remained unchallenged at the time of sentencing because . . . the judge said he would disregard [them]." Proposed Amendments to FED. R. CRIM. P. 32 advisory committee notes (prelim. draft 1981), reprinted in 30 CRIM. L. REP. (BNA) 3001, 3016 (1981). Inexplicably, however, the currently proposed amendments to Rule 32 fail to resolve this problem. The amendments merely codify the reliance exception by allowing the judge either to resolve factual disputes or to disregard the controverted material in sentencing, although a record of such actions taken by the sentencing judge would be appended to the PSI prior to its transfer to correctional agencies. Proposed Amendments to FED. R. CRIM. P. 32(c)(3)(D), reprinted in 30 CRIM. L. REP. (BNA) at 3014-15. 
fort to verify independently information in the PSI.$^{61}$ Nor are parole hearings designed to ensure accurate factfinding. ${ }^{62}$ Incarcerated and without rights to counsel, to present witnesses, or to confront sources of adverse information, ${ }^{63}$ inmates may be unable to marshall evidence to challenge misinformation in their PSIs successfully. As a result, offenders rarely prevail in challenges to PSI information made at parole hearings. ${ }^{64}$ Thus, PSI misinformation that is not tested at sentencing is unlikely to be corrected later in the parole process. ${ }^{65}$

Even at sentencing, furthermore, defendants may be subtly precluded from challenging information that is central to their sentencing decisions. Before imposing sentence, a judge will typically consider an offender's likely parole guidelines in order to determine a sentence that will result in a term of actual incarceration that the judge deems appropriate. ${ }^{66}$ In so doing, however, the judge implicitly relies on all of the information necessary to determine and apply the parole guidelines. While in theory this information should be subject to challenge under the "reliance exception" to Rule 32, in practice neither the judge nor the defendant may be aware of its subtle role in sentencing. ${ }^{67}$ As a result, judges may disclaim reliance

61. See supra p. 1229.

62. Cf. Project, supra note 24, at 834 ("prospective parolee often does not have a fair opportunity to rebut or respond to information derived from the PSI"). Parole hearings are conducted informally by non-lawyer hearing examiners. Often the examiners do not discuss or confirm information relevant to calculation of the guidelines with the inmate, but rely entirely on the PSI account. Id. at 833-37. Because many prisoners do not have a full understanding of the guidelines, they may not realize that misinformation was relied on to their detriment.

63. Although inmates are allowed to have a representative present at parole hearings, the latter's role is limited to making a short statement at the conclusion of the hearing. See 28 C.F.R. $\$ 2.13$ (b) (1981).

64. See Project, supra note 24, at 835-36 ("little or no weight given to contradictory accounts provided by the inmate in the hearing"). Cf. Masiello v. Norton, 364 F. Supp. 1133, 1136 (D. Conn. 1973) (hearing examiners "apparently accepted at face value some loosely-worded, unsupported assertions in the [presentence] report"). But cf. 28 C.F.R. $\$ 2.19$ (c) (1981) (Parole Commission must resolve disputes by a "preponderance of the evidence" standard).

65. Cf. Lupo v. Norton, 371 F. Supp. 156, 160 (D. Conn. 1974) (lack of "procedural due process protections [at] parole proceedings leaves prisoners exposed to the risk that untrue charges will jeopardize their chances for parole"); STANDARDS, supra note 1, § 18-3.1, at 200 ("procedural informality and general absence of counsel" at parole hearings "heighten the risk of . . factual error"); Project, supra note 24, at 835 (many inaccuracies "go unchallenged and uncorrected" in parole hearings).

66. See United States v. Slutsky, 514 F.2d 1222, 1229 (2d Cir. 1975) ("parole implications of a sentence are a necessary and important factor for the consideration of the sentencing judge"); United States v. DeMier, 520 F. Supp. 1160,1169 (W.D. Mo. 1981) (judges must "anticipate the . . guidelines" to insure period of custody consistent with their sentencing intentions); Note, Federal Parole Decisionmaking: Judicial Review for the Fortunate and Few, 85 DICKINSON L. REV. 501, 517 (1981) (many judges "fashion sentences that will achieve their purposes when acted upon by the guidelines"). See also Project, supra note 24, at 882 n.361 (88\% of the 64 district court judges who responded to survey stated that they considered parole in sentencing). The Judicial Council of the Second Circuit has approved just such an approach, recommending that judges in the circuit decide how much time an offender should serve and then select a sentence that accounts for the impact of the parole guidelines. See Judicial Council of the Second Circuit, Benchmarks Project para. 4 (approved Dec. 12, 1979) (on file with Yale Law Journal).

67. Many judges simply may be unaware of the information encompassed by the guidelines, since 
on some factors relevant to the parole guideline determination, ${ }^{68}$ and thereby preclude presentence challenge. In practice, therefore, the 1975 amendments to Rule 32 have proven inadequate as a means of ensuring accuracy at either sentencing or parole.

\section{A Right to Accuracy in PSIs}

The problem of inaccurate information in PSIs is of constitutional, statutory, and equitable significance. Due process requires that sentencing decisions be based on accurate information. This requirement should extend to the parole decision as well. In addition, the legislative histories of Rule 32 and the parole statute indicate that Congress intended complete accuracy in the sentencing and parole decisions of federal offenders. Finally, strong considerations of policy and equity interests support the fair and accurate treatment of defendants at all stages of the correctional process.

\section{A. Constitutional Grounds}

At sentencing, a convicted offender has a substantial liberty interest, protected by the due process clause of the Fifth Amendment, in avoiding deprivation of his or her freedom. ${ }^{69}$ Fundamental to this interest is the right to be sentenced on the basis of accurate and reliable information. ${ }^{70}$ Although the procedures constitutionally required to ensure such sentencing accuracy have not been clearly established, ${ }^{71}$ the Supreme Court held

typically the probation officer, rather than the judge, calculates an offender's likely parole guidelines and includes them in the PSI for the judge's consideration. See PSI MANUAL, supra note 10, at 16 (instructing probation officers to include parole guidelines in PSI). Furthermore, because many probation officers consider the parole guidelines in making their sentence recommendations, see Fennell \& Hall, supra note 12, at 1675, judges may unknowingly rely on the guideline information by adopting these recommendations. See supra p. 1228 (judges rely heavily on sentence recommendations of probation officers). Defendants and their counsel are also unlikely to recognize the possibility of implicit reliance on parole guidelines at sentencing. The probation officer's parole prediction is not generally disclosed to defense counsel, see Fennell \& Hall, supra note 12, at 1675; cf. United States v. Bazzano, 570 F.2d 1120, 1128 (3d Cir. 1977) (rejecting claim that court denied effective assistance of counsel by failing to disclose parole guidelines to defense counsel), cert. denied, 436 U.S. 917 (1978), who also may be unfamiliar with the parole guidelines.

68. See supra note 57 (citing examples of judicial disclaimer of reliance on information relevant to parole).

69. See Gardner v. Florida, 430 U.S. 349, 358 (1977) ("[T]he sentencing process, as well as the trial itself, must satisfy the requirements of the Due Process Clause."); Fennell \& Hall, supra note 12 , at 1638 (defendant has "liberty interest in avoiding deprivation of his freedom"); $c f$. Mempa v. Rhay, 389 U.S. 128, 137 (1967) (defendant has right to counsel at sentencing).

70. See United States v. Lee, 540 F.2d 1205, 1211 (4th Cir.) (defendant has due process right to be sentenced on basis of accurate information), cert. denied, 429 U.S. 894 (1976); Collins v. Buckhoe, 493 F.2d 343, 346 (6th Cir. 1974) (per curiam) (same); United States v. Espinoza, 481 F.2d 553, 555 (5th Cir. 1973) (same).

71. The Supreme Court has identified three factors that must be balanced in determining what process is due in a particular context: first, the nature of the private interest at stake; second, the risk of error under current practice and the probable value of additional procedural safeguards; and third, the government's interest. Mathews v. Eldridge, 424 U.S. 319, 335 (1976). Although this Note does 
over 30 years ago in Townsend v. Burke ${ }^{72}$ that a sentence founded on materially false information about the defendant violates due process. ${ }^{73}$

Insofar as judges base their sentencing decisions on parole guidelines and the information that underlies them ${ }^{74}$ Townsend demands that such information be sufficiently accurate and trustworthy to satisfy the dictates of due process. A sentence based in part on a parole prediction calculated from factual misinformation, therefore, violates due process.

The right to accuracy at sentencing should also extend to the parole stage. The federal parole system delegates sentencing authority, in large measure, to the Parole Commission. ${ }^{75}$ As Congress has recognized, federal parole is "an extension of the sentencing process." integral part of the sentencing process in the federal criminal system, ${ }^{77}$ constitutional claims to accuracy of information should apply with equal force to both sentencing and parole decisions. ${ }^{78}$

Moreover, the wording of the federal parole statute suggests that fed-

not, on these grounds, contend that current procedures under Rule 32 are constitutionally defective, strong policy arguments support the amendments to Rule 32 proposed here as a means of ensuring PSI accuracy at minimal cost. See infra pp. 1242-49.

72. 334 U.S. 736 (1948).

73. Id. at 740-41. See United States v. Tucker, 404 U.S. 443, 447 (1972) (sentence based on "misinformation of constitutional magnitude" violates due process); Roberts v. United States, 445 U.S. 552, 556 (1980) (citing Townsend and Tucker with approval). Although the Court in Townsend noted that the defendant was not represented by counsel, its reliance on the due process clause rather than the Sixth Amendment indicates that the consideration of misinformation, rather than absence of counsel, was central to the holding. Lower courts, therefore, have read the case broadly to invalidate any sentence based in part on misinformation. See, e.g., Moore v. United States, 571 F.2d 179, 182-83 (3d Cir. 1978); United States v. Harris, 558 F.2d 366, 373 (7th Cir. 1977); United States v. Weston, 448 F.2d 626, 634 (9th Cir. 1971), cert. denied, 404 U.S. 1061 (1972); United States v. Malcolm, 432 F.2d 809, 816 (2d Cir. 1970); Baker v. United States, 388 F.2d 931, 933 (4th Cir. 1968).

74. See supra p. 1236.

75. CORRECTIONS, supra note 22, at 86 (parole is "essentially a delegation of sentencing power to the parole board"); see Rodriguez v. United States Parole Comm'n, 594 F.2d 170, 175 (7th Cir. 1979) (Parole Commission, not sentencing judge, determines offender's punishment); Moore v. Nelson, 611 F.2d 434, 439 (2d Cir. 1979) (same). See also Hayward v. United States Parole Comm'n, 502 F. Supp. 1007, 1010 (D. Minn. 1980) ("Parole Commission's actions are tantamount to a resentencing"), rev'd on other grounds, 659 F.2d 857 (8th Cir. 1981); Buckhannon v. Hambrick, 487 F. Supp. 41, 43 (S.D.N.Y. 1980) ("ID]istrict judges no longer truly sentence a defendant. The parole guidelines do.").

76. S. REP. NO. 369, 94th Cong., 2d Sess. 15, reprinted in 1976 U.S. CODE CONG. \& AD. NEWS 335, 337; see H.R. CONF. REP. No. 838, 94th Cong., 2d Sess. 26, reprinted in 1976 U.S. CodE CONG. \& AD. NEWS 351, 358 ("Determinations of just punishment are part of the parole process . . . ").

77. See infra p. 1233 \& nn.50-52.

78. Cf. Project, supra note 24 , at $855-58$ (arguing that constitutional right to counsel at sentencing should apply at parole hearings). Several courts have held that because of the similarities between sentencing and parole, certain constitutional restrictions on the information that may be considered at sentencing apply equally at the parole stage. See Monks v. United States Parole Comm'n, 463 F. Supp. 859, 864-65 (M.D. Pa. 1978) (convictions based on involuntary confessons); Majchszak v. Ralston, 454 F. Supp. 1137, 1142-44 (W.D. Wis. 1978) (convictions obtained without counsel); Wren v. United States Bd. of Parole, 389 F. Supp. 938, 940-41 (N.D. Ga. 1975) (same). But see Dye v. United States Parole Comm'n, 558 F.2d 1376, 1379 (10th Cir. 1977) (Parole Commission may consider information which a court, for constitutional reasons, could not). 
eral inmates have an additional basis for a constitutional claim to accuracy at the parole stage. In Greenholtz v. Nebraska Penal Inmates, ${ }^{79}$ the Supreme Court held that the statutory language of the Nebraska state parole statute created a legitimate expectation of parole that was protected by due process safeguards. ${ }^{80}$ Although the Supreme Court has yet to address the question of whether such an entitlement is created by the federal parole statute, the similarities between the federal statute and the Nebraska statute examined in Greenholtz suggest that the federal law also embodies a protected liberty interest in parole. ${ }^{81}$

Finally, even if the function or statutory language of the federal parole system creates no due process interest, federal offenders may nonetheless have a general claim to accuracy in parole proceedings based upon the due process clause. Although the Court in Greenholtz rejected the claim that the mere possibility of parole creates a protected interest, ${ }^{82}$ the decision did not sanction arbitrary or demonstrably erroneous action by the Parole Commission. ${ }^{83}$ Thus, courts have consistently held that parole decisions

79. 442 U.S. 1 (1979).

80. Id. at 12. The Nebraska statute states that "the Board of Parole . . . shall order [an of[ender's] release unless" certain affirmative findings are made. NEB. REV. STAT. § 83-1, 114 (1976) (emphasis added). The Court limited its holding to the statute's "unique structure," 442 U.S. at 12, and stated that absent such a statutorily created entitlement, the mere hope of release on parole does not implicate due process. Id. at 11. Critics have suggested that Greenholtz ignores the liberty interest that offenders retain, even after conviction, in avoiding continued incarceration. See Case Note, 28 KAN. L. REV. 635, 644-45 (1980); Case Note, 63 MARQ. L. REV. 665, 674-75 (1980); see also Connecticut Bd. of Pardons v. Dumschat, 101 S. Ct. 2460, 2466 (1981) (Stevens, J., dissenting) (convicted offender "possesses a residuum of constitutionally protected liberty" even while incarcerated).

81. The federal statute states that "[i]f an eligible prisoner" satisfies certain criteria he or she "shall be released." 18 U.S.C. $\S 4206$ (a) (1976) (emphasis added). Moreover, the exercise of discretion by the parole authority is more closely circumscribed under the federal statute than the Nebraska scheme by the parole guidelines, which limit the factors relevant to the parole decision and from which the Parole Commission can only deviate upon a showing of good cause. See Evans v. Dillahunty, 662 F.2d 522, 526 (8th Cir. 1981) (discretion more limited in federal system than in Nebraska); cf. Greenholtz, 442 U.S. at 13 (Nebraska parole statute "vests very broad discretion in the [Parole] Board").

Based on these considerations, the Eighth Circuit has held that the federal parole statute creates a constitutionally-protected expectation of liberty. Dillahunty, 662 F.2d at 526. Two other courts have intimated similar conclusions. See Candelaria v. Griffin, 641 F.2d 868, 869 (10th Cir. 1981) (per curiam) (noting that federal parole statute is similar to Nebraska statute considered in Greenholtz); Bowles v. Tennant, 613 F.2d 776, 778 (9th Cir. 1980). But see Page v. United States Parole Comm'n, 651 F.2d 1083, 1086 (5th Cir. 1981) (per curiam) (asserting without discussion that federal parole statute creates no liberty interest).

82. 442 U.S. at 11 ("possibility of parole . . . not protected by due process").

83. See Greenholtz, 442 U.S. at 19 (Powell, J., concurring in part and dissenting in part) ("W] Wen a State adopts a parole system that applies general standards of eligibility, prisoners justifiably expect that parole will be granted fairly and according to law whenever those standards are met."); Block v. Potter, 631 F.2d 233, 235-36 (3d Cir. 1980) (Greenholtz does "not sanction totally arbitrary parole decisions"); cf. Moore v. Nelson, 611 F.2d 434, 439 (2d Cir. 1979) (Parole Commission's discretion must be exercised within statutory and constitutional bounds). Although the majority in Greenholtz noted that a case might arise in which a parole decision is made on the basis of "wholly inaccurate" information, the constitutional consequences of such a decision were not before the Court, and the Court did not address them. 442 U.S. at 15 n.7. 
based on false information about a defendant are inherently arbitrary, and hence constitutionally invalid. ${ }^{84}$

A general right to accuracy of information at sentencing and parole, however, does not require that judges and parole authorities reach the same ultimate decisions. ${ }^{85}$ Both authorities have wide discretion to determine the length of a defendant's actual term of incarceration, and they may reasonably disagree. ${ }^{86}$ Due process demands only that the decisions of both be founded on accurate factual information about the defendant. ${ }^{87}$

\section{B. Legislative Intent}

The legislative histories of Rule 32 and the Parole Commission and Reorganization Act ${ }^{88}$ clearly indicate Congress' concern that both sentencing and parole decisions be fair and accurate. The 1975 amendments to Rule 32 reflect an unequivocal congressional intent to make sentencing information more accurate. As originally proposed by the Advisory Committee and approved by the Supreme Court, the amendments would have allowed defendants only to review and comment on their PSIs prior to sentencing, with no actual challenge procedures. ${ }^{89}$ To ensure "that the presentence report be completely accurate in every material respect,"

84. See Little v. Hadden, 504 F. Supp. 558, 564 (D. Colo. 1980) (parole decision "not based on anything in the record" is arbitrary and capricious); Wren v. United States Bd. of Parole, 389 F. Supp. 938, 941 (N.D. Ga. 1975) (parole decision cannot be based on misinformation); Kohlman v. Norton, 380 F. Supp. 1073, 1075 (D. Conn. 1974) (parole decision "lacking any evidentiary support . . . denies petitioner the most elemental aspect of due process"); Masiello v. Norton, 364 F. Supp. 1133, 1136-37 (D. Conn. 1973) (parole decision with "no basis in fact" violates due process). The due process clause does not merely ensure procedural regularity; it protects the individual from being subjected to the arbitrary and unfounded application of otherwise satisfactory procedures. See Block v. Potter, 631 F.2d 233, 235-36 (3d Cir. 1980) (noting "fundamental due process right to be free from arbitrary governmental action"); cf. Wolff v. McDonnell, 418 U.S. 539, 558 (1974) ("touchstone of due process is protection of the individual against the arbitrary action of government").

85. In United States v. Addonizio, 442 U.S. 178 (1979) the Supreme Court held that actions of the Parole Commission inconsistent with the expectations and intent of the sentencing judge do not provide a basis for collateral attack on the original sentence. Id. at 190. But see United States v. DeMier, 520 F. Supp. 1160, 1169 (W.D. Mo. 1981) (criticizing Addonizio and holding that sentence based on incorrect parole predictions by sentencing judge violates defendant's right to be sentenced on the basis of accurate information and may be corrected by sentencing judge).

86. See, e.g., Musto v. United States, 571 F.2d 136, 137 (3d Cir. 1978) (upholding sentence despite sentencing judge's misapprehension of parole consequences); Kills Crow v. United States, 555 F.2d 183, 184 (8th Cir. 1977) (same); Buckhannon v. Hambrick, 487 F. Supp. 41 (S.D.N.Y. 1980) (same).

87. In United States v. Addonizio, 442 U.S. 178 (1979), the Court noted that petitioner's claim was "based not on any objectively ascertainable error but on the frustration of the subjective intent of the sentencing judge." Id. at 187. Addonizio's holding, therefore, does not preclude a due process attack on a sentence based on an erroneous parole prediction derived from factual inaccuracies about the defendant.

88. 18 U.S.C. § 4201 (1976).

89. See FED. R. CRIM. P. 32 advisory committee notes (1974 amendments) ("best way of insuring accuracy is disclosure" with opportunity to point out "inaccurate, incomplete or otherwise misleading" information).

90. H.R. REP. No. 247, 94th Cong., 1st Sess. 18, reprinted in 1975 U.S. CODE CoNG. \& AD. 
however, Congress strengthened these safeguards by adding language to permit defendants to present witnesses and other evidence to contest alleged inaccuracies in their PSIs. ${ }^{91}$

The policies underlying the 1976 Parole Commission and Reorganization Act ${ }^{92}$ similarly depend upon informational accuracy. The Senate Report reflects congressional concern that parole have "both the fact and appearance of fairness to all." ${ }^{\prime 93}$ To this end, Congress designed the Act to realize two goals: "equity between individual cases and a uniform measure of justice." accurate information, neither fairness nor uniform decisionmaking can be achieved. ${ }^{5}$

\section{Policy Considerations}

The interests of both society and criminal offenders are best served when fairness and accuracy are assured at all stages of the sentencing and correctional process. An offender's perception of fairness in the criminal justice system is thought to promote rehabilitation. ${ }^{96}$ Accurate sentencing and parole decisions also further society's interest in ensuring that offenders will be returned to society neither sooner nor later than is appropriate. ${ }^{97}$

Finally, the criminal justice system as a whole values and protects accuracy and the appearance of fairness. Prior to a finding of guilt, the criminal defendant is meticulously protected by a full array of safeguards designed to minimize the risk of errors and ensure the fairness of the ulti-

NEWS 674, 690 .

91. FED. R. CRIM. P. 32(c)(3)(A).

92. 18 U.S.C. $\S 4201$ (1976).

93. S. REP. NO. 369, 94th Cong., 2d Sess. 19, reprinted in 1976 U.S. CODE CONG. \& AD. NEWS 335,340 .

94. H.R. CONF. REP. NO. 838, 94th Cong., 2d Sess. 26, reprinted in 1976 U.S. CODE CONG. \& AD. NEWS $351,359$.

95. Cf. Moore v. United States, 571 F.2d 179, 184 (3d Cir. 1978) (sentence based on inaccurate information is irrational and unfair because "designed for an individual whose characteristics differ from those of the person on whom punishment actually is imposed").

96. See Morrissey v. Brewer, 408 U.S. 471, 484 (1972) ("[F]air treatment in parole revocations will enhance the chance of rehabilitation by avoiding reactions to arbitrariness."); In re Gault, 387 U.S. 1, 26 (1967) (fair treatment may promote rehabilitation of juvenile offenders); FED. R. CRIM. P. 32 advisory committee note (1974 amendments) ("[A]ccuracy of sentencing information is important . . . to effective correctional treatment of a convicted offender.").

97. Society's interest in appropriate prison terms based on accurate information is threefold. First, society has an interest in restoring offenders to a normal and productive life as soon as possible. See Morrissey v. Brewer, 408 U.S. 471, 484 (1972). Second, society benefits from minimizing the costs of incarceration. See S. REP. NO. 369, 94th Cong., 2d Sess. 16, reprinted in 1976 U.S. CODE CONG. \& AD. NEws 335, 337-38 (unwarranted continued incarceration of inmates "represents a misapplication of tax dollars"). Finally, society seeks to avoid the premature release of those offenders whose incarceration is necessary for the protection of society. See id. at 19,1976 U.S. CODE CONG. \& AD. NEWS at 341 ("[P]arole agency acts for society as its protector.") 
mate result. For the approximately ninety percent of all criminal defendants who plead guilty, however, sentencing and parole represent the primary basis for evaluating the fairness of the criminal justice system. ${ }^{98}$ Unless these two proceedings engender a perception that justice is done, the criminal justice system will be unable to muster the popular support necessary to legitimate its decisions. ${ }^{99}$

\section{Amending Rule 32 to Ensure PSI Accuracy}

In light of the constitutional, legislative history, and policy considerations that support a broad right to accuracy at both sentencing and parole, Rule 32 should be amended to permit presentence challenges to all PSI information relevant to either sentencing or parole. Although not constitutionally compelled, this proposal would secure defendants' constitutional right to accuracy, while minimizing costs to the overall criminal justice system by providing for all such challenges at a single hearing prior to sentencing.

\section{A. A Modified Rule 32}

The sentencing hearing provided by Rule 32 should be modified to allow challenges to any PSI information that is relevant to either the sentencing or parole decision. ${ }^{100}$ This approach is consistent with a broad view of sentencing as encompassing the entire decisionmaking process by

98. Cf. Coffee, supra note 21, at 1369 (sentencing and parole for most defendants "constitute their chief impressions of the fairness of the criminal justice system"); Shepard v. United States, 257 F.2d 293, 294 (6th Cir. 1958) (Stewart, J.) (surest measure of justice to a convicted criminal lies in the fairness of the sentence he receives).

99. See STANDARDS, supra note $1, \S 18-6.4$, at 452 ("Our concept of the dignity of the individual and our respect for the law itself suffer when so little attention is paid to a [sentencing] decision critically affecting individual liberty."); $c f$. Joint Anti-Fascist Refugee Comm. v. McGrath, 341 U.S. 123, 171-72 (1951) (Frankfurter, J., concurring) (fair process important in "generating the feeling, so important to a popular government, that justice has been done"). See generally Mashaw, Administrative Due Process: The Quest for a Dignitary Theory, 61 B.U.L. REV. 885 (1981) (arguing for a noninstrumentalist theory of due process).

100. Some courts have recognized the important interaction between the sentencing hearing and the parole decision with respect to PSI challenges. See United States v. Cesaitis, 506 F. Supp. 518, 522-23, 525 (E.D. Mich. 1981) (defendant permitted to supplement PSI with explanation of disputed material for consideration by Parole Commission because "time of sentencing is the logical point at which to consider inconsistencies in or incorrect statements about defendant's prior criminal record"); see also Wixom v. United States, 585 F.2d 920, 921 (8th Cir. 1978) (Parole Commission may not consider disputed PSI information not relied on by sentencing judge); United States v. Fatico, $458 \mathrm{~F}$. Supp. 388, 402 (E.D.N.Y. 1978) ("Defense counsel have an obligation to request that presentence reports be corrected lest serious errors in them be relied upon by prison or parole authorities . . ...), af'd, 603 F.2d 1053 (2d Cir. 1979), cert. denied, 444 U.S. 1073 (1980); cf. Pernetti v. United States, 21 CRIM L. REP. (BNA) 2033, 2034 (D.N.J. 1977) (Parole Commission may not consider counts of an indictment dismissed in plea agreement because "they have not been proven in any acceptable manner nor to any reliable extent"). Indeed, the Supreme Court has recognized that one of the major roles for defense counsel at sentencing is to adduce facts for later use by parole authorities. See Mempa v. Rhay, 389 U.S. 128, 135 (1967). 
which a defendant's actual length of incarceration is determined. ${ }^{101}$ To facilitate effective challenges to misinformation, subdivision $(c)(3)(B)$ of Rule 32 should also be amended to provide for summarization of all confidential information that is material. ${ }^{102}$

Under the modified Rule, an inmate who desires to challenge the accuracy of information in the PSI would first appeal directly to the probation officer who wrote the PSI. ${ }^{103}$ The probation officer would either verify the challenged information or remove it from the report. ${ }^{104}$ Factual disputes not settled through this process would be resolved at the sentencing hearing. If the controverted material was relevant to either sentencing or parole, ${ }^{105}$ the judge would resolve the dispute at this hearing, based on the evidence presented by both parties. Information the judge finds to be unsupported or irrelevant to the sentencing or parole decisions would be excised from the PSI. ${ }^{106}$ To ensure that these challenges are fair and mean-

101. See infra pp. 1233,1238 (parole is part of sentencing process).

102. Currently, subdivision (c)(3)(B) requires summarization only of confidential information actually relied on by the sentencing judge. When confidentiality is required, all undisclosed material information should be summarized with specificity to allow an opportunity for meaningful challenge. Sce United States v. Woody, 567 F.2d 1353, $1361-62$ (5th Cir.), cert. denied, 436 U.S. 908 (1978); United States v. Long, 411 F. Supp. 1203, 1207-08 (E.D. Mich. 1976). The confidentiality exceptions under subdivision (c)(3)(A), see supra note 42, however, should be construed narrowly to allow nondisclosure only when the risk of harm is significant. See FED. R. CRIM. P. 32(c)(3)(A) advisory committee notes (1974 amendment) ("In the absence of compelling reasons for nondisclosure of special information, the defendant and his counsel should be permitted to examine the entire presentence report.")

103. This "administrative remedy" process will help to screen out frivolous challenges and encourage the informal resolution of substantive disputes. Cf. ST $\Lambda$ ND $\wedge$ RDS, supra note $1, \S 18-5.5$, at 378 (recommending a presentence conference at which counsel for the government and the defendant would attempt to resolve PSI objections informally by stipulation); Fennell \& Hall, supra note 12, at 1678-79 (proposing PSI disclosure conference as a mechanism of informal dispute resolution).

104. Defendants may be able to resolve many disputes by merely explaining the specific errors to their probation officers, or by providing them with additional information. In other cases, further investigation, verification, or documentation by the probation officer may be necessary. When the probation officer can corroborate the contested information, he or she may be able to discourage the defendant from challenging it on the record. Finally, if the probation officer is unable to substantiate challenged information, or the information is irrelevant to both the sentencing and parole decisions, the officer should simply remove the material from the PSI. Cf. PSI MANUAL, supra note 10, at 5 ("By leaving out any information not related to the sentence decision, the probation officer produces reports that are factual, germane, precise, and succinct.")

105. Information relevant to sentencing means all information on which the judge chooses to rely. Information relevant to parole is defined, in large measure, by the factors incorporated into the parole guidelines, see supra notes 53-55 (describing guidelines), and also includes any information that pertains to the severity of the offense, the culpability of the defendant, or parole prognosis. See PAROLE MANUAL, supra note 53, at 125-28 (describing reasons for decisions outside of parole guidelines). The judge should construe relevance broadly to insure that all pertinent information contested by the defendant is open to correction at sentencing.

106. Currently, the sentencing judge disregards unsupported or irrelevant information, but it remains in the PSI and may be considered at the parole hearing. See supra note 59. Excision of unsupported or irrelevant information, however, is necessary to balance competing concerns of expediency, full information, and accuracy. If judges were required to resolve disputes through formal hearings regarding any PSI information, in some cases scarce judicial resources would be expended resolving challenges to extraneous material. On the other hand, were judges allowed simply to disregard, but not excise, challenged material that is irrelevant to either sentencing or parole, judges would be 
ingful, the defendant, already afforded the right to counsel, would be allowed to present witnesses and documentary evidence and to confront and cross-examine adverse witnesses. ${ }^{107}$

The burden of proof at the sentencing hearing should be fairly distributed between the offender and the government. First, the burden of production should be on the defendant. ${ }^{108}$ Unless the defendant challenges PSI information at sentencing, its validity should be accepted. ${ }^{109}$ To meet this burden, the defendant should have to explain his or her objections to particular items in the PSI in sufficient detail to place the PSI's accuracy in doubt. ${ }^{110}$ Once a defendant raises a sufficient challenge, the burden of

tempted to avoid delay by simply finding information irrelevant, cf. Coffee, supra note 21, at 1424-25 (noting ease of judicial evasion of summation requirements of Rule 32(c)(3)(B) by disclaiming reliance), and circumvent the procedural protections this proposal would provide. Although the possibility exists that judge might mistakenly remove from the PSI material that is actually relevant to later correctional decisions, systemic pressures from the probation office and Parole Commission would tend to minimize this risk.

107. Insofar as federal offenders have a constitutional right to informational accuracy, see supra pp. 1237-1240, such procedures may be constitutionally required. In Morrissey v. Brewer, 408 U.S. 471,489 (1972), the Supreme Court held that before an offender's parole can be revoked, due process requires that he or she be afforded the rights to written notice of the charges, to be apprised of the evidence against him or her, to be heard in person, to present witnesses and documentary evidence, and to confront and cross-examine adverse witnesses. The Court extended these rights to probation revocation proceedings in Gagnon v. Scarpelli, 411 U.S. 778, 782 (1973), and further held that probationers and parolees have a qualified due process right to counsel. Id. at 790 . Courts and commentators alike have suggested that similar rights should be required to resolve factual disputes regarding PSIs at sentencing. See, e.g., United States v. Fatico, 441 F. Supp. 1285, 1293 (E.D.N.Y. 1977) ("Like the parolee, the convicted defendant about to be sentenced has at stake a liberty interest; its 'termination inflicts a grievous loss.' ") (quoting Morrissey, 408 U.S. at 482), rev'd. on other grounds, 579 F.2d 707 (2d Cir. 1978); Coffee, supra note 21, at 1423 (absence of procedural protections at sentencing comparable to those at parole revocations "appear[s] to be an increasingly isolated anomaly" in the law); Note, Recent Developments in the Confidentiality of Pre-sentence Reports 40 ALB. L. REV. 619, 632 (1976) (same procedural safeguards afforded at parole revocation should apply at sentencing). Indeed, some federal courts currently allow cross-examination at sentencing hearings. See, e.g. United States ex rel. Brown v. Rundle, 417 F.2d 282, 285 (3d Cir. 1969) (when disputed information is "obviously significant"); United States v. Fatico, 458 F. Supp. 388 (E.D.N.Y. 1978), aff', 603 F.2d 1053 (2d Gir. 1979), cert. denied, 444 U.S. 1073 (1980). Several states also allow crossexamination at sentencing. See, e.g., State v. Horne, 56 N.J. 372, 376, 267 A.2d 1, 3 (1970); OHIO REV. CODE ANN. $\$ 2947.06$ (Page 1975) (defendant may cross-examine court appointed psychologist or psychiatrist); VA. CODE $\$ 19.2-299$ (Supp. 1982) (defendant may cross-examine investigating officer on any information in PSI).

108. See STANDARDS, supra note 1, $\$ 18-6.4$, at 465 (defendant should have initial burden of production); Note, $A$ Hidden Issue of Sentencing: Burdens of Proof for Disputed Allegations in Presentence Reports, 66 GEO. L.J. 1515, 1529 (1978) (same).

109. See, e.g., Williams v. New York, 337 U.S. 241, 244 (1949) (rejecting need for sentencing hearing after noting that accuracy of PSI not challenged by defendant or his counsel); United States v. Fatico, 579 F.2d 707, 713 (2d Cir. 1978) (hearsay statements in PSI not disputed by defendant are admissible at sentencing); United States v. Bass, 535 F.2d 110, 121 (D.C. Cir. 1976) ("absence of a denial itself provides an important indicia of reliability").

110. Cf. United States v. Robin, 545 F.2d 775, 782 (2d Cir. 1976) ("appellant's repeated and unequivocal objections . . . to the veracity of the sentencing data" raise "a serious question respecting accuracy"). A general denial or challenge without explanation should not be enough to trigger a sentencing hearing. See United States v. Trevino, 490 F.2d 95, 96 (5th Cir. 1973) (per curiam) (rejecting challenge to sentencing information because "appellant has not directly and specifically denied [its] truth"); United States ex rel. Petri v. Warden, Allenwood Fed. Prison Camp, 507 F. Supp. 5, 7 (M.D. Pa. 1980) (defendant's "vague allegations of inaccuracies [in the PSI] . . do not warrant 
persuasion should shift to the government. ${ }^{111}$ Considerations of fairness, ${ }^{112}$ efficiency, ${ }^{113}$ and relative availability of resources to the two parties ${ }^{114}$ dictate this allocation. Finally, the standard of persuasion for the government should be one of "clear and convincing evidence." 15 Stricter than the "preponderance of the evidence" standard used in civil suits, ${ }^{116}$ the clear and convincing standard is commonly required when a liberty interest is at stake, in order to minimize the risk of erroneous deprivations. ${ }^{117}$ This

any action"); STANDARDS, supra note $1, \S 18-6.4$, at 465 ("mere pro forma objection" insufficient to meet burden of production). By requiring a specific denial of particular facts in the PSI, this burden of production will impede frivolous claims or general challenges to the PSI as a whole, without penalizing defendants whose access to relevant evidence may be severely limited. But see Note, supra note 108, at 1530-31 (arguing that to promote judicial economy, defendant should be required to adduce "some evidence" to carry burden of production).

111. See United States v. Weston, 448 F.2d 626, 634 (9th Cir. 1971) (impermissible to place burden of refutation on defendant once he has thrown reasonable doubt on reliability of material information in PSI), cert. denied, 404 U.S. 1061 (1972); United States v. Fatico, 441 F. Supp. 1285, 1294 (E.D.N.Y. 1977) (same), rev'd on other grounds, 579 F.2d 707 (2d Cir. 1978); STANDARDS, supra note $1, \S 18-6.4$, at 465 (once defendant "effectively challenges" PSI, burden of persuasion should fall on government); Note, supra note 108, at 1538 (same).

112. See United States v. Weston, 448 F.2d 626, 634 (9th Cir. 1971) (noting difficulty of "proving a negative," and declaring it a "miscarriage of justice to expect [a defendant] to assume the burden" of disproving unsupported allegations of confidential informant), cert. denied, 404 U.S. 1061 (1972).

113. Knowing that the government bears the burden of persuasion, probation officers will be hesitant to include allegations in the PSI which they cannot support. As a result, PSIs will become more accurate, and challenges will be less frequent. See Note, supra note 108, at 1536-37 (placing burden on government will increase accuracy of PSIs).

114. The government has greater resources than the defendant in terms of investigative contacts, personnel, and money. Thus, although the defendant may have greater knowledge of the accuracy of the PSI, the government's resource advantage places it in a better position to adduce additional evidence to support challenged allegations. See United States v. Weston, 448 F.2d 626, 634 (9th Gir. 1971) (defendant should not be put to expense of disproving PSI), cert. denied, 404 U.S. 1061 (1972); Note, supra note 108, at 1537 (defendant's ability to produce "hard evidence" may be limited due to lack of resources).

115. See Note, supra note 108, at 1543 (clear and convincing standard accommodates defendant's right to accuracy and society's interest in judicial economy); $c f$. Hollis v. Smith, 571 F.2d 685, 695 (2d Cir. 1978) (rejecting "beyond a reasonable doubt" standard); United States v. Fatico, 458 F. Supp. 388, 408-09 (E.D.N.Y. 1978) (advocating changing standards of proof and "clear, unequivocal and convincing evidence" standard when important facts being disputed), afTd, 603 F.2d 1053 (2d Cir. 1979), cert. denied, 444 U.S. 1073 (1980).

116. The preponderance standard is used in civil cases since "we view it as no more serious in general for there to be an erroneous verdict in the defendant's favor than for there to be an erroneous verdict in the plaintifTs favor." In re Winship, 397 U.S. 358, 371 (1970) (Harlan, J., concurring). In contrast, because "it is far worse to convict an innocent man than to let a guilty man go free," id. at 372 , the "beyond a reasonable doubt" standard is required in criminal cases. Id. at 364 (opinion of the Court). Similarly, to the extent that convicted offenders have a constitutional right to accuracy, the law should err in favor of the defendant at sentencing. See infra pp. 1245-46 \& nn.117-18; $c$. Addington v. Texas, 441 U.S. 418, 427 (1979) ("The individual should not be asked to share equally with society the risk of error when the possible injury to the individual is significantly greater than any possible harm to the state.") See generally United States v. Fatico, 458 F. Supp. 388, 402-12 (E.D.N.Y. 1978) (discussing various standards of proof), aff'd 603 F.2d 1053 (2d Cir. 1979), cert. denied, 444 U.S. 1073 (1980).

117. See In re Ballay, 482 F.2d 648, 662 (D.C. Cir. 1973) (proof by clear, unequivocal and convincing evidence frequently required where interests of society are pitted against individual liberty). The Supreme Court has applied the clear and convincing standard-or a similar intermediate requirement-in a number of contexts roughly analagous to that of a sentencing hearing. See, e.g., 
standard, therefore, reflects the importance of the right to accuracy in the criminal context. ${ }^{118}$

Once an offender has had an opportunity for PSI challenge, the offender and correctional agencies would be bound by the results of the Rule 32 hearing. ${ }^{119}$ Thus, executive agencies in the criminal justice system such as the Parole Commission or the Bureau of Prisons could rely on PSIs without challenge by disgruntled offenders. ${ }^{120}$ An offender's only recourse should he or she discover inaccurate information in the PSI following sentencing would be to petition the sentencing judge to order the material removed from the PSI. ${ }^{121}$ Such motions should be granted, however, only if the offender can show some good cause for not having challenged the information at sentencing. ${ }^{122}$

Addington v. Texas, 441 U.S. 418, 433 (1979) (involuntary civil commitment hearing); Woodby v. INS, 385 U.S. 276, 285-86 (1966) (deportation hearing); Chaunt v. United States, 364 U.S. 350,353 (1960) (denaturalization hearing); Gonzales v. Landon, 350 U.S. 920, 920 (1955) (per curiam) (expatriation hearing).

118. The American Bar Association advocates only a preponderance of the evidence standard of persuasion for sentencing hearings. See STANDARDS, supra note 1, $\S 18-6.4(\mathrm{c})$, at 448; see also Alschuler, Sentencing Reform and Parole Release Guidelines, 51 U. CoLO. L. REV. 237, 240 (suggesting preponderence standard). Somewhat inconsistently, however, the ABA also recommends a clear and convincing standard for probation revocation hearings, STANDARDS, supra note 1 , $\S 18-$ $7.5(e)$, at 525 , on the ground that "a liberty interest should not be sacrificed simply on the "preponderance' standard." Id. at 533. This observation ignores the fact that the important liberty interest at stake at sentencing justifies the same standard of persuasion. Cf. Fennell \& Hall, supra note 12, at 1639 (defendant at sentencing has stronger liberty interest than parolee or probationer whose liberty has already been restricted).

119. Currently, the Parole Commission is not bound to accept the findings of the court at a sentencing hearing. See H. Hoelter, Director of National Center on Institutions and Alternatives, Testimony before the Committee on Rules of Practice and Procedure of the Judicial Conference of the United States 6 (Feb. 10, 1982) ("Parole Commission can simply ignore the court's finding" on disputed facts) (on file with Yale Law Journal). Cf. Standlee v. Rhay, 557 F.2d 1303, 1307 (9th Cir. 1977) (parole revocation may be based on charges of which defendant was acquitted, because of lower standard of proof); Mack v. McCune, 551 F.2d 251, 254 (10th Cir. 1977) (per curiam) (parole revocation may be based on conviction that was reversed). Moreover, the court's findings are frequently not communicated to the Parole Commission. See supra note 59.

120. Of course, should the offender present evidence demonstrating an inaccuracy which was not challenged at sentencing, the Parole Commission could, in its discretion, accept the offender's version. The correctional agencies must, however, accept all findings on disputes resolved at sentencing, whether for or against the defendant. Similarly, all PSI information not challenged at sentencing must be presumed true. See United States ex rel. Goldberg v. Warden, Allenwood Fed. Prison Camp, 622 F.2d 60, 66 (3d Cir. 1980) (Parole Commission may normally presume accuracy of PSI unchallenged at sentencing), cert. denied, 449 U.S. 871 (1980).

121. See United States ex rel. Petri v. Warden, Allenwood Fed. Prison Camp, 507 F. Supp. 5, 7 (M.D. Pa. 1981) (directing plaintiff who claims parole decision based on PSI misinformation to "seek a correction of the report from the sentencing court"); United States v. Cesaitis, 506 F. Supp. 518 (E.D. Mich. 1981) (motion to correct PSI); Rosati v. Haran, 459 F. Supp. 1148 (E.D.N.Y. 1977) (mandamus action to correct PSI).

122. See, e.g., United States v. Plisek, 657 F.2d 920, 924-25 (7th Cir. 1981) (defendant's failure to challenge accuracy of PSI at sentencing constitutes waiver of his right to do so); United States v. Leonard, 589 F.2d 470, 472 (9th Cir. 1979) (same); United States v. Brice, 565 F.2d 336, 338 (5th Cir. 1977) (same). But of. Diaz Torres v. United States, 564 F.2d 617, 619 (1st Cir. 1977) (for challenges initiated after sentencing, court requires explanation justifying delay and excusing failure to make challenge at sentencing); United States v. Harris, 558 F.2d 366, 375-76 (7th Cir. 1977) (allowing defendant to challenge PSI not disputed at sentencing, in part because defense counsel ne- 


\section{B. Benefits of the Proposed Modification}

The proposed modification to Rule 32 is advantageous on grounds of both fairness and efficiency. First, because PSIs will be more accurate and reliable, both sentencing and parole decisons are more likely to be appropriate for particular offenders. ${ }^{123}$ At the same time, defendants will be more likely to perceive their sentence and parole decisions as fair, thus enhancing the prospects for their rehabilitation. ${ }^{124}$ Moreover, because disputes relevant to the parole decision will be resolved prior to sentencing, judges will be better able to predict the actual incarceration consequences of sentences, and hence to render sentences of appropriate length. ${ }^{125} \mathrm{Fi}-$ nally, because the offender and the Parole Commission will be bound to accept the findings of Rule 32 hearings, this proposal will eliminate the possibility that the Parole Commission will rely on information found to be unreliable at the sentencing hearing. ${ }^{126}$

The proposal also will remedy the present inefficient division of labor between the sentencing judge and the Parole Commission by combining all PSI challenges in a single hearing. Because all disputes will be resolved at sentencing, the offender will be assured a meaningful opportunity to challenge information in the PSI. All challenges will be heard by a trial judge, an expert in resolving adjudicative disputes. ${ }^{127}$ The defendant

glected to examine PSI prior to sentencing).

123. To the extent that parole decisions will be based on more accurate information, the predictive value of the guidelines will be enhanced and the likelihood that an inmate will be improperly rated on the guidelines and released at a time inconsistent with the best interests of the offender or society will be minimized. See United States v. Cesaitis, 506 F. Supp. 518, 521 (E.D. Mich. 1981) (accurate information will sharpen parole predictions); $c f$. Project, supra note 24, at 864-65 (salient factor score loses its predictive value when based on false information).

124. Because challenges will be formalized and fully resolved, defendants will be more likely to believe that they were fairly heard and not the victims of caprice. CF. STANDARDS, supra note $1, \S 18-$ 6.4, at 452 (suggesting that "a cavalier informality at sentencing alienates the offender," thereby frustrating rehabilitation); Campbell, Sentencing: The Use of Psychiatric Information and Presentence Reports, $60 \mathrm{KY}$. L.J. 285, 303 (1971-72) (if allowed to participate at sentencing, defendant "cannot justly feel . . . that he is a pawn of the whims of the judge or the probation officer or both") (quoting federal Judge Roszel C. Thomsen). See also infra p. 1241 (fair treatment aids rehabilitation).

125. As a result of the Court's holding in United States v. Addonizio, 442 U.S. 178 (1979), judges are powerless to adjust their otherwise accurate sentences on the ground that the Parole Commission has frustrated their sentencing intent. See supra notes $85 \& 87$ (describing Addonizio). If the judge predicts incorrectly the decision of the Parole Commission, the offender may be incarcerated for longer than the judge considers appropriate. See, e.g., Banks v. United States, 553 F.2d 37, 40 n.8 (8th Gir. 1977) (after Parole Commission denied defendant parole, sentencing judge wrote to Commission: "There is no way to justify a $36-45$ month confinement for this man."); see also supra note 86 . The ability of a judge to determine an appropriate sentence, therefore, hinges on his success in forecasting the decisions of the Parole Commission. See Curtis, supra note 25, at 108.

126. See infra note 119 (Parole Commission currently may make findings of fact inconsistent with those of sentencing judge).

127. See Alschuler, supra note 118 , at 240 (sentencing court in better position than Parole Commission to resolve factual disputes). In those cases that go to trial, the sentencing judge will already be familiar with the defendant. 
will also be protected by an array of due process safeguards, including the right to counsel..$^{128}$ Furthermore, at sentencing, the probation officer who wrote the PSI is readily available to testify while the information in the report is still fresh in his or her mind. For these reasons, the sentencing hearing is the logical forum for resolving all PSI disputes. ${ }^{129}$

Because limited sentencing hearings are currently provided pursuant to Rule 32, the benefits of this proposal are likely to outweigh its expected costs. Costs will largely be attributable to delay from longer sentencing hearings, additional investigation, and loss of unverifiable though possibly accurate information from the PSI. Admittedly, the PSI challenges permitted under this proposal will inevitably lengthen some sentencing proceedings. To the extent that sentencing is the only opportunity for most defendants to develop the facts upon which their terms of incarceration will be based, ${ }^{130}$ however, delays due to more extensive investigations and hearings are justified. ${ }^{131}$ In addition, the incidence of frivolous challenges should be minimal in light of defendants' tactical desire to avoid antagonizing the sentencing judge. ${ }^{132}$

The proposal would limit the costs of investigation and loss of information by committing to the discretion of the probation officer the decision of whether disputed material should be substantiated or removed from the PSI. ${ }^{133}$ Through this mechanism, only those disputes relevant to the sentencing or parole decisions will be investigated and resolved; other challenged information will simply be removed from the report. By making the probation officer directly responsible for the accuracy of the PSI, the proposal may also improve the overall quality of PSIs, thereby decreasing the number of challenges in the long run. ${ }^{134}$

128. See United States v. Cesaitis, 506 F. Supp. 518, 525 (E.D. Mich. 1981) (burden on offender to correct or explain PSI while imprisoned "is obviously considerably greater than when he is before the Court represented by counsel").

129. Id. ("most logical and fair point of time to correct the presentence report is before [it] leaves control of the Court").

130. See Note, Due Process in Sentencing: A Right to Rebut the Presentence Report? 2 HAS. TINGS CONST. L.Q. 1065, 1069 (1975) ("critical determination of factual issues takes place at sentencing and not at trial" for most defendants).

131. Fear of delay was also a major objection to the 1975 amendments to Rule 32 . Yet, a recent empirical study concluded that this fear was groundless, finding that only $15 \%$ of the 154 judges questioned thought that sentencing now takes longer than it did prior to 1975. See Fennell \& Hall, supra note 12, at 1689 .

132. See Note, supra note 107 , at 624 (defense counsel would not risk antagonizing judge with dilatory tactics); Note, Disclosure of Presentence Reports: A Constitutional Right to Rebut Adverse Information by Cross-Examination, 3 RUT.-CAM. L. REV. 111, 126 (1971) (same); Note, supra note 37, at 841 (same).

133. These costs are interrelated. As investigation costs go up, for example, more disputed material in the PSI will be verified or corrected, and information costs, accordingly, will go down.

134. See supra note 113 ; cf. STANDARDS, supra note $1, \S 18-6.4$, at 458 (additional procedures at sentencing, "even if time consuming, serve the goal of judicial economy in the long run"). In addition, costs incurred at sentencing may be ofiset to a large extent by savings to the Parole Commission, 


\section{Presentence Reports}

\section{Conclusion}

Accurate information is indispensible to fair decisionmaking. Although constitutional, statutory, and policy arguments support an offender's right to accuracy at both sentencing and parole, this goal has not yet been fully realized. Rule 32 of the Federal Rules of Criminal Procedure should be modified, therefore, to allow a full airing of all challenges to information in the PSI that will affect the length of an offender's incarceration. This modification would enhance the accuracy of all PSI information relevant to either sentencing or parole, and thereby secure a defendant's right to have his or her term of incarceration determined on the basis of accurate information.

which will no longer be obliged to hear challenges to the PSI. Moreover, as sentencing and parole decisions become more fair and accurate, the costs may well be offset by a decrease in the number of motions for reduction of sentence, administrative parole appeals, petitions for writs of habeas corpus, and ultimately, in recidivism by unrehabilitated offenders. 